\title{
PENGARUH DAYA MICROWAVE TERHADAP YIELD PADA EKSTRAKSI MINYAK ATSIRI DARI BUNGA KAMBOJA (PLUMERIA ALBA) MENGGUNAKAN METODE MICROWAVE HYDRODISTILLATION
}

\author{
Nove Kartika Erliyanti ${ }^{1}$, Elsa Rosyidah ${ }^{2}$ \\ 1Program Studi Teknik Kimia Universitas Nahdlatul Ulama Sidaorjo, Jl.Monginsidi Dalam Kav. \\ DPR Sidoklumpuk Sidoarjo 61218 \\ 2Program Studi Teknik Lingkungan Universitas Nahdlatul Ulama Sidaorjo, Jl.Monginsidi Dalam \\ Kav. DPR Sidoklumpuk Sidoarjo 61218 \\ Nomor Telepon: (031) 7970900 / 807900 \\ E-mail: nove.kartika.nke@gmail.com
}

\begin{abstract}
Frangipani oil is one of the most expensive essential oils. Conventional extraction methods has many disadvantages, so the microwave hydrodistillation method is used as an alternative to optimize the quality and quantity of frangipani oil. The purpose of this study was to investigate the effect of microwave power on the yield of frangipani oil. The research stage was carried out by inserting frangipani flower that has been cut into the flask and mixed with different aquadest solvent volumes of $300,400,500$, and $600 \mathrm{ml}$. The flask put into the microwave with different powers of 300, 450, and $600 \mathrm{~W}$ for three hours. The resulting vapor is collected and separated in a separating funnel. The process is carried out at atmospheric pressure and the operating temperature is $100{ }^{\circ} \mathrm{C}$. Finally, the yield percentage determined from resulting product. The results showed that microwave power had a significant effect on the yield percentage of frangipani oil. The yield percentage increased with increasing the microwave power. The highest yield percentage was generated at 600 Watt, 25 gram flower mass, and $600 \mathrm{ml}$ volume, which was $1,612 \%$.
\end{abstract}

Kata Kunci: essential oil, hydrodistillation, microwave, frangipani oil

\section{PENDAHULUAN}

Indonesia mempunyai sumber daya alam hayati yang sangat banyak dan beragam yang sampai saat ini masih belum dimanfaatkan secara optimal. Salah satu dari keanekaragaman hayati yang sangat banyak dan beragam terdapat tanaman yang berpotensi menghasilkan minyak atsiri. Indonesia menghasilkan 40 - 50 jenis tanaman penghasil minyak atsiri dari 80 jenis minyak atsiri yang diperdagangkan di dunia dan baru sebagian dari jenis minyak atsiri tersebut yang memasuki pasar dunia, salah satunya adalah minyak atsiri aromatik. Saat ini dikembangkan jenis-jenis minyak atsiri aromatik yang dihasilkan dari berbagai bunga yang ada di Indonesia. Berbagai jenis bunga di Indonesia yang berpotensi menghasilkan minyak atsiri belum banyak dimanfaatkan, salah satunya adalah bunga kamboja (Plumeria alba).

Kamboja banyak ditemui di Pulau Jawa dan Bali, di mana pada umumnya bunga kamboja hanya dimanfaatkan dalam upacara keagamaan dan sebagian besar dibuang dan tidak dimanfaatkan. Kamboja juga banyak dijumpai di area pemakaman. Bunga kamboja mengandung beberapa senyawa atsiri yang menyebabkan bunga tersebut berbau harum [1] senyawa-senyawa atsiri yang terdapat dalam kamboja diantaranya geraniol, farsenol, sitronelol, fenetilalkohol, dan linalool [2]. Minyak kamboja (Frangipani Essential Oi) bisa dimanfaatkan sebagai bahan campuran sabun, obat nyamuk, body lotion, dan minyak wangi.

Faktor-faktor yang mempengaruhi mutu minyak kamboja secara garis besar adalah jenis dan kualitas kamboja yang akan diambil minyaknya, metode penyulingan, jalannya proses penyulingan, pengemasan serta penyimpanan minyak kamboja yang dihasilkan. Kualitas minyak kamboja juga dipengaruhi oleh teknik budidaya, umur panen, proses pengeringan, dan lamanya waktu penyimpanan stelah pengeringan [3]. 
Untuk menaikkan harga jual minyak kamboja dan mengoptimalkan potensi minyak kamboja yang ada di Indonesia, maka dilakukan usaha untuk menaikkan mutu minyak kamboja tersebut sehingga sesuai dengan standar mutu yang telah ditentukan. Salah satu usaha yang dilakukan diantaranya adalah menentukan kondisi operasi agar proses penyulingan/ekstraksi minyak kamboja dapat memenuhi standar mutu yang berlaku. Kondisi operasi yang paling mendasar dalam proses ekstraksi minyak kamboja adalah lama waktu ekstraksi, komposisi bahan baku, dan laju pemanasan.

Penelitian tentang berbagai macam metode ekstraksi dan analisis kualitas komponen minyak atsiri bunga kamboja telah banyak dilakukan. [4] telah melakukan penelitian tentang macam-macam metode ekstraksi dan analisis kualitas komponen minyak atsiri dari bunga kamboja dengan jenis bunga kamboja Plumeria obtuse L. Penelitian tentang pengambilan minyak atsiri dari bunga kamboja dengan metode distilasi air (water distillation) telah dilakukan oleh [5]. Metode water distillation menghasilkan yield yang cukup tinggi, namun kualitas yang dihasilkan kurang bagus. Oleh karena itu perlu dikembangkan metode ekstraksi yang dapat meningkatkan kuantitas dan kualitas dari minyak atsiri tersebut. Salah satu metode ekstraksi yang telah dikembangkan saat ini adalah ekstraksi dengan menggunakan microwave.

Penelitian terdahulu menunjukkan bahwa ekstraksi dengan alat microwave merupakan alternatif yang bisa terus dikembangkan daripada metode konvensional, karena tingginya kadar kemurnian produk, minimnya pemakaian solvent, dan waktu proses yang singkat [Ferhat, 2006 6]. Metode yang berhasil dikembangkan adalah metode microwave hydrodistillation (MHD) yang merupakan kombinasi antara penyulingan air dengan pemanas microwave [7].

Berdasarkan uraian tersebut, maka dilakukan penelitian tentang ekstraksi bunga kamboja dengan memanfaatkan gelombang mikro serta air sebagai pelarut (microwave hydrodistillation) serta bertujuan untuk mengetahui pengaruh daya microwave terhadap yield minyak kamboja yang dihasilkan.

\section{METODOLOGI PENELITIAN}

Penelitian ekstraksi minyak atsiri dari bunga kamboja (Plumeria alba) dengan menggunakan metode microwave hydrodistillation akan dilakukan melalui dua tahap. Tahap pertama dari penelitian ini adalah bunga kamboja (Plumeria alba) dibersihkan, dijemur, kemudian dipotong dengan ukuran $\pm 2 \mathrm{~cm}$. bunga kamboja yang telah dipotong tersebut kemudian dioven selama 4 hari.

Tahap kedua dari penelitian ini adalah proses ekstraksi minyak atsiri dengan menggunakan microwave dan pelarut aquadest. Penelitian ekstraksi minyak atsiri dari bunga kamboja dilakukan dalam sistem yang ditunjukkan pada Gambar 1.

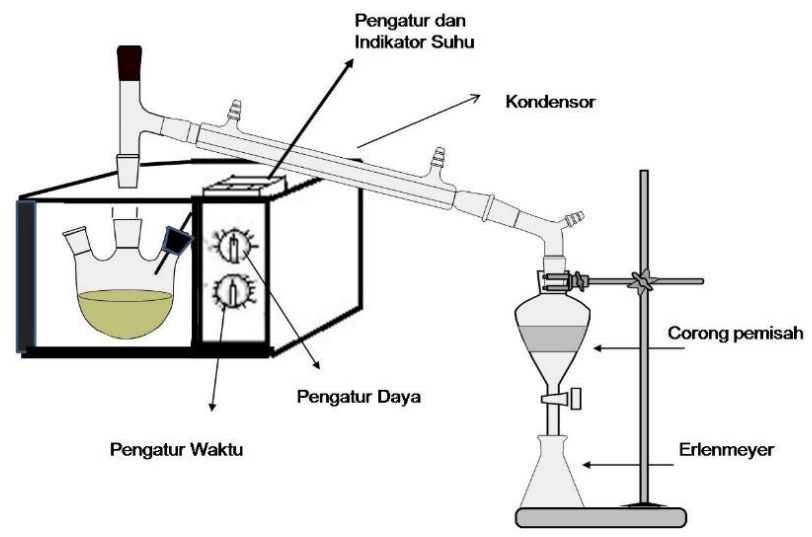

Gambar 1 Skema Alat Ekstraksi Minyak Atsiri dari Bunga Kamboja Menggunakan Metode Microwave Hydrodistillation

Bunga kamboja yang telah dipotong dan dioven selama 4 hari kemudian ditimbang sebanyak 25 gram dan 50 gram. Bunga kamboja yang telah ditimbang dimasukkan ke dalam labu 1 liter (massa yang dimasukkan sesuai dengan variabel yang telah ditentukan, yaitu 25 gram atau 50 gram) dan dicampur dengan pelarut aquadest (volume 300, 400, 500 , dan $600 \mathrm{ml}$. Labu yang berisi campuran bunga dan pelarut kemudian dimasukkan ke dalam microwave yang telah dilengkapi dengan thermocouple dan temperature control. Proses ekstraksi dioperasikan pada tekanan atmosfir dan temperatur $\pm 100^{\circ} \mathrm{C}$, dibantu oleh gelombang mikro dengan daya 300,450 , dan 600 Watt selama 3 jam. Sebuah kondensor dihubungkan ke dalam reaktor (labu 1 liter) 
yang berfungsi merubah fase uap menjadi fase cair. Uap yang dihasilkan melewati kondensor kemudian didinginkan sampai suhu $30^{\circ} \mathrm{C}$ dan menghasilkan destilat yang terdiri dari fase

\section{HASIL DAN PEMBAHASAN \\ Pengaruh Daya Microwave terhadap \% Yield Minyak Kamboja}

Daya adalah banyaknya energi yang dihantarkan per satuan waktu (Joule/sekon). Daya microwave dan suhu saling berhubungan, karena daya yang tinggi dapat menaikkan suhu operasi di atas titik didih pelarut dan menghasilkan peningkatan yield hasil ekstraksi. Daya microwave berperan sebagai driving force untuk untuk memecah struktur membran sel tanaman, sehingga minyak dapat terdifusi keluar dan larut dalam pelarut. Jadi, penambahan daya secara umum akan meningkatkan yield dan mempercepat waktu ekstraksi [8].

Daya dalam ekstraksi microwave akan mengontrol besarnya energi yang akan diterima oleh bahan untuk dirubah menjadi energi panas. Energi panas inilah yang membantu proses keluarnya minyak atsiri dari bahan atau sampel.

Daya microwave yang digunakan dalam penelitian ini adalah 300, 450, dan 600 Watt, volume pelarut $300,400,500$, dan $600 \mathrm{ml}$, serta massa bunga kamboja 25 dan 50 gram. Pengaruh daya microwave ditunjukkan pada Gambar 2 dan Gambar 3.

Pada Gambar 2 dapat diketahui bahwa semakin tinggi daya microwave dan semakin besar pelarut maka \% yield yang dihasilkan memiliki kecenderungan naik. Persen (\%) yield tertinggi dengan massa bunga kamboja 50 gram diperoleh pada daya microwave $600 \mathrm{~W}$, volume pelarut $600 \mathrm{ml}$ yaitu sebesar 1,286\%. Daya microwave memiliki pengaruh yang signifikan terhadap \% yield minyak kamboja. Hal ini dikarenakan semakin besar daya, maka suhu operasi meningkat dan laju penyulingan (penguapan) menjadi semakin besar. Kenaikan suhu adalah akibat dari kemampuan bahan dan pelarut untuk menyerap energi dari gelombang mikro. Semakin besar daya maka semakin besar energi yang diterima bahan untuk dirubah menjadi panas sehingga yield minyak kamboja semakin besar. Hal ini dikarenakan semakin besar daya, maka suhu operasi meningkat dan laju penyulingan minyak dan air. Destilat tersebut dipisahkan antara minyak dan air dengan menggunakan corong pemisah. Produk yang dihasilkan kemudian ditentukan \% yield nya.

(penguapan) menjadi semakin besar. Kenaikan suhu adalah akibat dari kemampuan bahan dan pelarut untuk menyerap energi dari gelombang mikro. Ukuran yang menunjukkan kemampuan untuk menyerap gelombang mikro disebut konstanta dielektrik. Semakin besar daya maka semakin besar energi yang diterima bahan untuk dirubah menjadi panas sehingga yield minyak kamboja semakin besar.

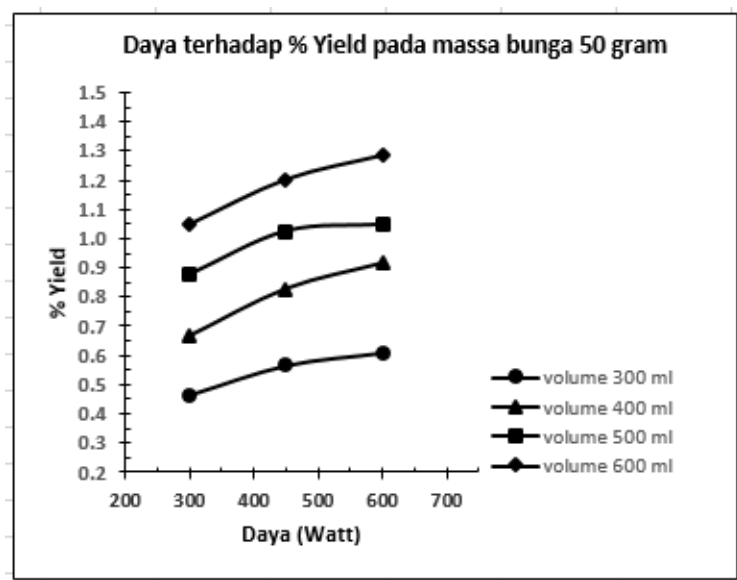

Gambar 2 Pengaruh Daya Microwave terhadap \% Yield Minyak Kamboja, Massa Bunga Kamboja 50 gram

Pengaruh daya microwave terhadap \% yield minyak kamboja dengan massa kamboja 25 gram ditunjukkan pada Gambar 3.

Pada Gambar 3 dapat diketahui bahwa semakin tinggi daya microwave dan volume pelarut maka \% yield yang dihasilkan memiliki kecenderungan naik. Persen (\%) yield tertinggi dengan massa bunga kamboja 25 gram diperoleh pada daya microwave $600 \mathrm{~W}$, volume pelarut $600 \mathrm{ml}$ yaitu sebesar $1,612 \%$.

Daya microwave memiliki pengaruh yang signifikan terhadap \% yield minyak kamboja. . Hal ini dikarenakan semakin besar daya, maka suhu operasi meningkat dan laju penyulingan (penguapan) menjadi semakin besar. 


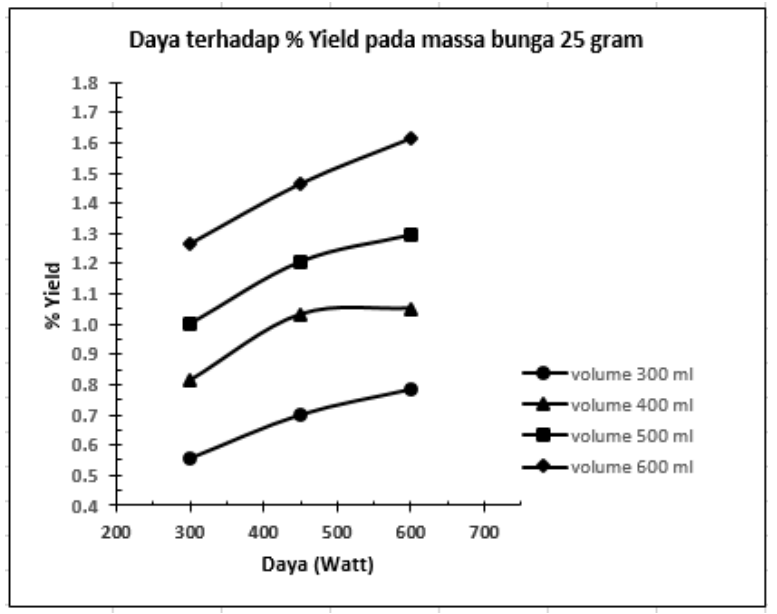

Gambar 3 Pengaruh Daya Microwave terhadap \% Yield Minyak Kamboja, Massa Bunga Kamboja 25 gram

Kenaikan suhu adalah akibat dari kemampuan bahan dan pelarut untuk menyerap energi dari gelombang mikro. Ukuran yang menunjukkan kemampuan untuk menyerap gelombang mikro disebut konstanta dielektrik. Semakin besar daya maka semakin besar energi yang diterima bahan untuk dirubah menjadi panas sehingga yield minyak kamboja semakin besar.

Pada Gambar 2 dan 3 dapat diketahui bahwa \% yield mengalami penurunan seiring dengan bertambahnya massa bahan baku yang digunakan. Hal ini disebabkan penambahan massa bahan yang dgunakan sudah terlampau banyak (padat) dan hampir memenuhi volume labu distiller, sehingga uap menjadi sulit berpenetrasi dalam bahan untuk membawa molekul minyak terdifusi keluar dari bahan. Tingkat kepadatan bahan berhubungan erat dengan besar ruangan antar bahan. Kepadatan bahan yang terlalu tinggi dan tidak merata menyebabkan terbentuknya jalur uap "rate holes" yang dapat menurunkan yield dan mutu minyak [9]

\section{KESIMPULAN}

Kesimpulan dari penelitian ini adalah daya microwave mempunyai pengaruh yang signifikan terhadap \% yield minyak kamboja yang dihasilkan. Semakin tinggi daya microwave dan volume pelarut, maka semakin besar \% yield yang dihasikan. Persen (\%) yield tertinggi dihasilkan pada daya $600 \mathrm{~W}$, volume
$600 \mathrm{ml}$, massa 25 gram yaitu sebesar 1,612 $\%$.

\section{DAFTAR PUSTAKA}

[1] Zaheer, Z., Konale, A. G., Patel, K. A., Subur, K. W., Farooqui, M. N., 2010, Plumeria Rubra Linn., An Indian Medicinal Plant, International Journal of Pharmacy \& Therapeutics, 1, $2: 116-119$.

[2] Farooque, A. M. D., Mazunder, A., Shambhawee, S., Mazumder, R., 2012, Review on Plumeria Acuminata, International Journal on Research in Pharmacy and Chemistry, $2: 2$.

[3] Hernani, Marwati, T., 2006, Peningkatan Mutu Minyak Atsiri Melalui Proses Pemurnian, Balai Besar Litbang Pascapanen Pertanian, Bogor.

[4] Pitpiangchan, Potechaman dkk, 2009, Comparative Study of Scented Compound Extraction from Plumeria obtusa L, Bangkok Thailand Institute of Scientific and Technological Research.

[5] Firdaus, H., Saputro, A. D., 2011, Pengambilan Minyak dari Bunga Kamboja dengan Metode Distilasi Air (Water Distillation), Jurnal Pomit ITS : $1-3$.

[6] Ferhat, M., Chemat, F., Meklati, B., Smadja, J., 2006, An Improved Microwave Clevenger Apparatus for Distillation of Essential Oils from Orange Peel, Journal of Chromatography A, Vol.1112: 121 - 126.

[7] Stashenko, E., E., Jaramillo, B. E., Martinez, J. R., 2004, Comparison of Different Extraction Methods for the Analysis of Volatile Secondary Metabolites of Lippia alba (Mill) N.E. Brown, Grown in Colombia, and Evaluation of Its in vitro Antioxidant Activity, J. Chromatography. A, Vol. 1025:93.

[8] Liang, H., Hu, Z., Cai, M., Desirability Function Approach for the Optimization of Microwave-Assisted Extraction of Saikosaponins from Radix Bupleuri, Sep Purif Technology 61 (3) : 266 - 275.

[9] Guenther, Ernest, 1987, Minyak Atsiri Jilid I, Penerjemah Ketaren S, Cetakan I, Universitas Indonesia Press, Jakarta. 